\title{
PHRASEOLOGICAL UNITS WITH ONOMASTIC COMPONENTS: THE CASE OF ENGLISH AND SLOVENE*
}

\author{
UNIDADES FRASEOLÓGICAS CON COMPONENTES \\ ONOMÁSTICOS: EL CASO DEL INGLÉS Y DEL ESLOVENO
}

\author{
ALENKA VRBINC \\ University of Ljubljana. Ljubljana, Slovenia \\ alenka.vrbinc@ef.uni-lj.si \\ MARJETA VRBINC \\ University of Ljubljana. Ljubljana, Slovenia \\ marjeta.vrbinc@ff.uni-lj.si
}

\begin{abstract}
The article discusses English and Slovene phraseological units with onomastic components. The research is based on two databases: an English one comprising 172 phraseological units and a Slovene one consisting of 324 phraseological units. The phraseological units are studied to determine which proper names form components of English and Slovene phraseological units and how frequently they appear in English and Slovene. Then, the universality or cultural specificity of phraseological units in both languages is investigated, bearing in mind that phraseological units with onomastic components are very often culture-specific because they refer to a unique denotatum belonging to the national culture. As is evident from the analysis of English and Slovene phraseological units, reference in English as well as in Slovene phraseological units is often made to people or places with which the members of the respective culture are familiar. On the other hand, many phraseological units with the same origin are more universally used in several languages with the same cultural and historical background, which also holds true of English and Slovene. The final finding is that proper names that are components of phraseological units and which are characteristic of a given culture should be observed from different points of view, such as historical, geographical, cultural, linguistic, cross-linguistic and social, and that more thorough studies of phraseological units with an onomastic component would contribute to a higher level of cross-cultural awareness.
\end{abstract}

Keywords: Phraseological units, onomastic component, universality, cultural specificity.

* "Theoretical and applicative research into languages: contrastive, synchronic and diachronic aspects" (No P6-0218). Faculty of Arts, University of Ljubljana and is financed by the Slovene Research Agency. 


\section{RESUMEN}

El artículo trata de las unidades fraseológicas inglesas y eslovenas y sus componentes onomásticos. La investigación se funda en dos bases de datos: la inglesa con 172 unidades fraseológicas y la eslovena con 324 unidades fraseológicas. Las unidades fraseológicas se investigan con el fin de determinar cuáles son los nombres propios que aparecen como componentes en las unidades fraseológicas eslovenas e inglesas y con qué frecuencia aparecen en inglés y en esloveno. A continuación se estudia la universalidad y las especificidades culturales de las unidades fraseológicas en ambas lenguas, teniendo en cuenta que las unidades fraseológicas con componentes onomásticos tienen frecuentemente rasgos culturales específicos porque se refieren a un denotatum único perteneciente a la cultura nacional. Del análisis de las unidades fraseológicas eslovenas e inglesas se desprende que las referencias, tanto en las unidades fraseológicas inglesas como en las eslovenas, se hacen a menudo a personas o lugares que los miembros de cada cultura conocen o les son familiares. Por otra parte, muchas unidades fraseológicas que tienen el mismo origen se usan de una manera más universal en las lenguas con el mismo contexto histórico-cultural, lo que vale también para el esloveno y el inglés. Al final se llega a la conclusión de que los nombres propios, componentes de las unidades fraseológicas que son típicas para una cultura dada, deben observarse desde diferentes puntos de vista: histórico, geográfico, cultural, lingüístico, translingüístico y social. Asimismo se concluye que algunos estudios profundizados sobre los componentes onomásticos en diferentes lenguas podrían contribuir a una conciencia transcultural más amplia.

Palabras clave: Unidades fraseológicas, componente onomástico, universalidad, especificidad cultural.

Recibido: 20/01/2013. Aceptado: 28/08/2013.

\section{INTRODUCTION}

proper noun is a noun denoting a particular person, a tame animal, country,
town, star, planet, or thing and is normally not preceded by an article or
other limiting modifier. In English, Slovene and in many other languages, proper
nouns are spelt with a capital letter. A proper noun, which is a single word, should
be distinguished from a proper name, which may or may not consist of more
than one word. Like other grammatical categories, the class of proper nouns has
unclear boundaries. For example, a number of common nouns with unique de-
notation are close to proper nouns and are sometimes spelt with a capital letter
(e.g., Fate, Nature) (Quirk, Greenbaum, Leech \& Svartvik, 1985: 288). On the
other hand, a proper name can take on a metaphorical meaning and become a
common noun: e.g., eponyms originating from a person's name (boycott $>$ from
the Irish landlord Captain Charles Cunningham Boycott; dablia $>$ from the Swed-
ish botanist Anders Dahl; volt from the Italian physicist Count Alessandro Volta)
or literary, biblical or mythological sources (malapropism > from the name of the 
character Mrs Malaprop in Sheridan's play The Rivals; (as) old as Methuselah > from Methuselah, a man in the Bible who is supposed to have lived for 969 years; aphrodisiac > from the Greek goddess of love and beauty Aphrodite).

The article discusses proper names used in phraseology. In the field of phraseology, different terms are used by different researchers to refer to a string of two or more words functioning as a whole and a single term may be used in reference to different phenomena. Granger and Meunier (2008: xix) attribute the lack of standardized terminology to the fact that phraseology has only relatively recently become established as a discipline in its own right. They explain that it deals with the study of word combinations rather than single words and that these multi-word units are classified into various subtypes on the basis of the following criteria: degree of semantic non-compositionality, syntactic fixedness, lexical restrictions and institutionalization.

'Idiom' is certainly a term that is widely used and the term most monolingual English dictionaries use (besides the term 'phrases') to introduce a section listing multi-word lexical items, whether semantically opaque or not, although they make no further typological classification. However, as Moon (1998a: 3-5) rightly points out, 'idiom' is an ambiguous term that she uses only occasionally to refer loosely to semi-transparent and opaque metaphorical expressions. She therefore prefers the term 'fixed expressions and idioms', which covers different kinds of phrasal lexemes, phraseological units, or multi-word lexical items, including idioms (ibid: 2). Gläser (1998: 125), on the other hand, defines an idiom as a dominant subtype within the all-embracing category of the phraseological unit, saying that an idiom is "a lexicalized, reproducible word group in common use, which has syntactic and semantic stability, and may carry connotations, but whose meaning cannot be derived from the meanings of its constituents". 'Phraseological unit' is another term that is increasingly used in phraseological research to denote a stable combination of words with a fully or partially figurative meaning (Kunin: 1970: 210 ), or a lexicalized, reproducible bilexemic or polylexemic word group in common use, which has relative syntactic and semantic stability, may be idiomatized, may carry connotations, and may have an emphatic or intensifying function in a text (Gläser, 1998: 125). According to Gläser (1984: 348), phraseological unit is used in some Slavonic and German linguistic traditions as a superordinate term for multi-word lexical items. 'Phraseme' is also used as a superordinate term (e.g., in Mel'čuk, 1995, but also in Slovene phraseological research, e.g, Kržišnik, 2010: 84), though not in the Anglo-American tradition. Other terms also encountered in the phraseological literature are multi-word lexical unit (Cowie, 1992), fixed expression (Moon, 1992a, Svensson, 2008), fixed phrase (Verstraten, 1992) and phrasal lexeme (Lyons, 1977: 23, Moon, 1998b: 79) (cf. also Moon, 1998a: 2-5, Naciscione, 2010: 17-19).

In this article, the term phraseological unit (PU) is used to refer to a two- or 
multi-word lexical item whose syntax and lexis are fixed, which is conventionalized and whose meaning is not predictable from the meaning of its constituent words. The emphasis is on phraseological units with a proper name (either a toponym or an anthroponym) or its derivative, the aim being to investigate the degree of cultural specificity of such PUs. A PU can be regarded as culture-specific only in contrast to another language; consequently, this characteristic comes to the foreground when comparing two languages. As Dobrovol'skij and Piirainen (2005: 245) claim, speakers perceive PUs with a proper name typical of a given national culture as being culturally connoted.

Szerszunowicz (2009: 172) proposes interdisciplinary studies, especially ethno-linguistic analyses, to ensure a proper approach to idiomatic expressions viewed as carriers of cultural connotations. As early as 1929, Weisgerber (1929) talked about the world-view shared by all members of a linguo-cultural community which makes possible the production and comprehension of metaphorical linguistic meanings in a subconscious process of insight. Teliya, Bragina, Oparina \& Sandomirskaya (1998: 56-57) stress that language is the means of representing and reproducing culture. Culture is assumed to be implemented on the content plane of linguistic expressions, reproduced in an act of denomination and transmitted from generation to generation through linguistic and cultural norms of usage. Consequently, language can be seen as an important mechanism in the formation of a collective cultural identity. Kržišnik (2008: 33-34) also claims that PUs are often carriers of cultural connotation. She takes examples from Slovene phraseology and studies possible sources for the culture-specific interpretation of phraseology. These sources refer to basic culture-specific approaches: i.e., ethnolinguistic, linguo-cultural and contrastive approaches. Doubtlessly, a PU used in discourse must be understood by the receiver. This process of comprehension is influenced by linguistic, social and cultural factors (Szerszunowicz, 2008: 119).

In our research, we investigate a number of English and Slovene PUs with an onomastic element to pursue several aims. When analysing the PUs, we first wanted to establish which proper names form components of the English and Slovene PUs under review. Second, we tried to establish how frequently they appear in English and Slovene. Third, the focus of our attention was the universality or cultural specificity of PUs in both languages, bearing in mind that PUs with onomastic components are very often so culture-specific that they exist in one culture only and consequently in only one language.

\section{METHODOLOGY}

For the purposes of our research, two databases were compiled, one consisting of 172 English PUs with either proper names or derivatives from proper names and 
the other one consisting of 324 Slovene PUs with onomastic components. The English PUs were selected with the help of the following five idiom dictionaries: Collins COBUILD Dictionary of Idioms, Oxford Idioms Dictionary for Learners of English, Chambers English Dictionary of Idioms, Cambridge International Dictionary of Idioms and Dictionary of Idioms and their Origins. In Slovene, there is a scarcity of dictionaries available, so the database was compiled mostly with the help of the Slovar slovenskega knjižnega jezika (Dictionary of Standard Slovene) and the FidaPlus corpus.

It has to be pointed out that many PUs with the same origin are more universally used in several languages with the same cultural and historical background, which also holds true of English and Slovene. Since we presupposed that the etymology of individual PUs would be helpful in our analysis, we included it in our databases wherever it can be traced.

\section{ONOMASTIC COMPONENTS IN ENGLISH AND SLOVENE PUs}

First of all, the proper names and their derivatives that are constituent elements of PUs were analysed to determine which onomastic components are used. It is evident from the PUs constituting the English and Slovene databases created for the purpose of this study that proper names and their derivatives can be divided into the following groups (for frequency of onomastic components in PUs see Table I):

1) male names:

a) full forms:

English: Dennis, Godfrey, John, Paul, Peter, Simon

Slovene: Andrej, Anton, Ciril, Fabijan, Florjan, Gabrijel, Gregor, Jakob, Janez, Jernej, Jožef, Jurij, Lovrenc, Luka, Martin, Matija, Medard, Mihael, Pavel, Peter, Tomaž, Urban, Valentin, Vid, Vincenc

b) hypocorisms:

English: Bill, Bob, Charley, Dick, Harry, Jack, Johnny, Larry, Mickey, Nick, Pete, Sam, Tom

Slovene: Janezek, Jure, Miha, Pepe, Til, Vinko

c) originating in mythology or history:

English: Achilles, Croesus, Cupid, Damocles, Janus, Jove, Midas

Slovene: Krez

d) originating in the Bible or other literary sources:

English: Adam, Aladdin, Cain, Don Juan, Hyde, Jekyll, Jesus, Job, Methuselah, Mohammed, Thomas

Slovene: David, Goljat, Metuzalem, Mohamed, Juda, Simon 
2) derivatives from male names:

English: Gordian, Pyrrhic (both of them are derived from mythological male names)

Slovene: Adamov, Ahilov, Aladinov, Amorjev, Avgijev, Blažev, Damoklejev, Jakobov, Judežev, Kajnov, Martinov, Matjažev, Pirov, Sizifov, Tantalov, Urbanov, Vidov (Slovene derivatives are all adjectives expressing possession and are derived either from common Slovene names or from names originating in mythology, history, the Bible or other literary sources)

3) male name + family name:

a) name and family name of a real person:

English: Gordon Bennett, Heath Robinson, John Hancock, Rube Goldberg

Slovene: Poncij Pilat ${ }^{1}$

b) literary characters or cartoon characters:

English: John Bull, Johnny Canuck, Simon Legree, Peter Pan

Slovene: Martin Krpan, Peter Klepec

c) character from a song:

English: Jim Crow, John Dory

d) origin uncertain:

English: Davy Jones, Jack Robinson, Joe Bloggs, Joe Blow, Joe Doakes, John Doe, John Thomas, Mickey Finn

e) miscellaneous:

English: John Henry (believed to be a Western United States cowboy variation of John Hancock)

Slovene: Janez Novak (an invented combination of a common male name and a common family name)

4) female names:

a) full forms:

English: Jane

Slovene: Barbara, Cecilija, Elizabeta, Katarina, Lucija, Magdalena, Marjeta, Matilda, Uršula, Vida, Zofija

b) hypocorisms:

English: Nellie/Nelly, Sally

Slovene: Jera, Jedrt, Micka, Polona, Urša, Zofka

c) originating in mythology:

English: Pandora

${ }^{1}$ In the PU hoditi od Poncija do Pilata ('walk from Pontius to Pilatus'), the name Poncij (= Pontius) and the family name Pilat (= Pilatus) are separated by the preposition do, the reason probably lies in the idiomaticity of the language. 
d) literary character:

English: Topsy

5) derivatives from female names:

Evin, Marjetin, Pandorin (these derivatives are all adjectives expressing possession and derived from common Slovene names and from a name from mythology)

6) female name + family name:

a) name and family name of a real person: Fanny Adams

b) origin uncertain: Jane Doe (feminine form of John Doe)

7) family names:

a) family names of real people: Hobson, McCoy, Murphy, Parkinson, Scott

b) cartoon character, literary character, hero of a song: Blimp, Frankenstein, Riley

c) common British family name: Jones

8) derivatives from family names:

English: Freudian

Slovene: Murphyjev (= Murphy), Potemkinov (= Potemkin) (the Slovene derivatives are adjectives expressing possession)

9) place names:

a) names of countries:

English: China, Brazil, England, Vietnam

Slovene: Amerika (= América), Bosna (= Bosnia), Teksas (= Texas)

b) names of towns, cities, villages:

English: Acapulco, Bristol, Coventry, Damascus, Kilkenny, Newcastle, Rome, Waterloo

Slovene: Babilon (= Babylon), Benetke (= Venice), Damask (= Damascus), Dunaj (= Vienna), Filipi (= Philippi), Gomora (= Gomorrah), Rim (= Rome), Sodoma (= Sodom), Spodnji Kašelj, Waterloo, Zgornji Kašelj

c) names of counties:

English: Cheshire

d) miscellaneous:

English: Charybdis (a whirlpool), Clapham (the name of a district of southwest London), Forth Bridge (a bridge), Fort Knox (a military reservation, location of US federal gold depository), Nod (a pun on the biblical place name), Rubicon (a river), Scylla (a rock), Tin Pan Alley (the name of a district in New York). 
Slovene: Betajnova (part of the town of Vrhnika), Canossa/Kanosa (the name of the castle), Indija Koromandija (imaginary word referring to a land where everything is in abundance), Karibda (= Charybdis), Luna (= the Moon), Olimp (= Mount Olympus), Parnas (= Mount Parnassus), Polje (part of Ljubljana), Rubikon (= Rubicon), Sava (a river), Scila (= Scylla)

10) derivatives from place names:

a) adjectives derived from place names:

English: American, British, Dutch, French, Indian, Russian, Swiss, Trojan Slovene: angleški (= English), babilonski (= Babylonian), danski (= Danish), egiptovski (= Egyptian), gordijski (= Gordian), hrvaški (= Croatian), italijanski (= Italian), kitajski (= Chinese), laški (= archaic for Italian), nürnberški (= Nuremberg), ruski (= Russian), saharski (= Saharan), sibirski (= Siberian), slovenski (= Slovene), španski (= Spanish), špartanski (= Spartan), švicarski (= Swiss), trojanski (= Trojan), turški (= Turkish), vietnamski (= Vietnam)

b) nouns derived from place names:

English: Dutchman, English, Englishman, French, Indian, Roman, Trojan Slovene: Bizantinec (= Byzantine), Francoz (= Frenchman), Turek (= Turk)

c) adverbs derived from place names:

Slovene: francosko (= in a French way)

11) derivatives from the names of tribes or ethnic groups:

a) nouns derived from the names of tribes or ethnic groups:

English: Mohican

Slovene: Cigan (= Gypsy), Mohikanec (= Mohican)

b) adjectives derived from the names of tribes or ethnic groups:

Slovene: $\operatorname{ciganski}$ (= Gypsy), danajski (= Danai), huronski (= Huron)

12) name of a heavenly body:

Slovene: Luna (= Moon)

13) name of a ship:

English: Titanic

The frequency of onomastic components in PUs as presented above varies in that some onomastic components are more frequently used than others, and some are limited to one language only. Table I shows the frequency of onomastic components in the two languages.

${ }^{2}$ In Slovene, the adjective gordijski is derived from the place name Gordij (= Gordium), as opposed to English, where Gordian is derived from the male name Gordius. 
Table I: Frequency of onomastic components in PUs analysed.

\begin{tabular}{|c|c|c|c|c|}
\hline \multirow[t]{2}{*}{ Onomastic components in PUs } & \multicolumn{2}{|c|}{$\begin{array}{c}\text { English PUs } \\
(\mathrm{n}=172)\end{array}$} & \multicolumn{2}{|c|}{$\begin{array}{c}\text { Slovene PUs } \\
(\mathrm{n}=324)\end{array}$} \\
\hline & No. & $\%$ & No. & $\%$ \\
\hline 1. Male names & 55 & 31.98 & 158 & 48.77 \\
\hline 2. Derivatives from male names & 3 & 1.74 & 34 & 10.49 \\
\hline 3. Male name + family name & 21 & 12.21 & 3 & 0.93 \\
\hline 4. Female names & 6 & 3.50 & 41 & 12.65 \\
\hline 5. Derivatives from female names & 0 & 0.00 & 6 & 1.85 \\
\hline 6. Female name + family name & 2 & 1.16 & 0 & 0.00 \\
\hline 7. Family names & 9 & 5.23 & 0 & 0.00 \\
\hline 8. Derivatives from family names & 1 & 0.58 & 2 & 0.62 \\
\hline 9. $\quad$ Place names & 30 & 17.44 & 32 & 9.88 \\
\hline 10. Derivatives from place names & 43 & 25.00 & 28 & 8.64 \\
\hline $\begin{array}{l}\text { 11. Derivatives from the names of tribes } \\
\text { or ethnic groups }\end{array}$ & 1 & 0.58 & 12 & 3.70 \\
\hline 12. Name of a heavenly body & 0 & 0.00 & 8 & 2.47 \\
\hline 13. Ship's name & 1 & 0.58 & 0 & 0.00 \\
\hline
\end{tabular}

A close observation reveals that anthroponyms and toponyms form the vast majority of PUs containing an onomastic component (with the exception of only a negligible number of PUs in both databases whose component is neither an anthroponym nor a toponym, cf. groups $11,12,13)$. As can be seen from the figures presented in Table I, among personal names that are a component of English as well as Slovene PUs, male names (found in 31.98\% of English and $48.77 \%$ of Slovene PUs) far outnumber female names (3.50\% of English and $12.65 \%$ of Slovene PUs), and the same holds true of the English PUs consisting of either a male name and family name (12.21\% of English PUs) or a female name and family name (only $1.16 \%$ of English PUs) ${ }^{3}$. These findings are in line with Pierini (2008: $6)$, who states that the predominance of male names can be due to socio-cultural factors, since men have played a more active role in society than women.

Toponyms (17.44\% of English and $9.88 \%$ of Slovene PUs) and derivatives from toponyms (25.00\% of English and $8.64 \%$ of Slovene PUs) can also be found in both the English and Slovene PUs but less often than anthroponyms, which again confirms the findings of Pierini (2008: 6).

${ }^{3}$ In Slovene, the percentage of PUs with the combination '(male/female) name + family name' is so insignificant that it does not permit valid comparison. 


\section{CULTURAL SPECIFICITY OF ENGLISH AND SLOVENE PUS WITH ONOMASTIC COMPONENTS}

Some PUs can be more universally used than others; they can be easily translated, and metaphorical meaning can be more easily deduced. PUs may have their roots in language history (Gläser, 1988: 267). The most common idioms can have deep roots, date back many centuries, and be traceable across many languages. Many have translations in other languages and tend to become international. We can trace parallel fixed expressions in different languages, and we can talk about the universality of some human situations and about cultural specificity. A crucial point is that the situations are cultural constants or cultural universals; only the precise metaphors realizing them differ. The real cultural importance is not the lexis or metaphor in use, but the situation for which a shorthand mode of reference has been developed (Moon, 1992b: 18-19).

It can doubtlessly be pointed out that cultures are typically localized; therefore, PUs are frequently not used outside that local context. This also applies to PUs containing a proper name. The metaphorical use of proper names reflects cultural specificities, which can also be seen when comparing English onomastic PUs with the Slovene ones. Culture-specific lexical items pose problems when a non-native speaker tries to comprehend or translate them. That is why Teliya et al. (1998: 55) advocate the point that linguo-cultural studies, or the analysis of PUs for cultural data as represented in linguistic meanings are of great importance, which is also proved by the analysis of the English and Slovene PUs with an onomastic element.

In order to establish what is a cultural universal and what a cultural specificity, it is necessary to investigate the origin of PUs. In the case of PUs containing an onomastic component, the origin of the entire PU can mostly, though not exclusively, be explained with the help of the origin of the proper name. As can be seen in Section 3, personal names are the most frequent components of PUs. They come from different sources, ranging from common English or Slovene names, and hypocorisms, to names originating from the Bible, other literary sources, mythology or history.

Cultural constants are most commonly found in PUs whose onyms' connotations have an international character, which means that they originate either from mythology and history (e.g., an/sb's Achilles heel-Ahilova peta, (as) rich as Croesus - bogat kot Krez/krez, althe sword of Damocles - Damoklejev meč, Gordian knot - gordijski vozel, cut/untie the Gordian knot - presekati/razvozlati gordijski vozel, Pandora's box - Pandorina skrinjica, a Pyrrhic victory - Pirova zmaga, a Trojan horse - trojanski konj) or the Bible ((as) old as Methuselah - star kot Metuzalem, a good Samaritan - usmiljeni samarijan, a doubting Thomas - nejeverni Tomaž). All these expressions are lexically identical in both languages. This can be explained by the fact that the common European linguistic and cultural heritage has had a strong 
influence on English as well as on Slovene PUs.

On the other hand, the PUs consisting of common English names and hypocorisms have no counterparts in Slovene and vice versa, thus causing problems in interlingual contact. Let us first enumerate some culture-specific English PUs and their equivalents in Slovene:

a jack/Jack of all trades - mojster za vse ('a craftsman for everything')

I'm all right, Jack - brigajo me drugi, jaz sem v redu ('I don't care about others, I'm all right')

a plain Jane - ne posebej privlačna ženska ('a not very attractive woman')

(as) happy as Larry - zelo vesel ('very happy')

Nervous Nellie - plašljivec ('a shy person')

full of the Old Nick - pravi hudic ('real devil')

the Old Bill - kifeljc ('cop')

a Peeping Tom - kdor opazuje druge ljudi pri slačenju ('someone who watches other people taking off their clothes')

for Pete’s sake - za božjo voljo ('for God's sake')

rob Peter to pay Paul - vzeti denar kje in ga dati kam drugam ('take money from somewhere and put it somewhere else')

Aunt Sally - tarča posmeha ('target of ridicule')

an Uncle Tom - črnec, ki skuša ustreči belcem ('a black person who tries to please white people')

every/any Tom, Dick andlor Harry - kdor koli ('anyone')

All the above-mentioned PUs have been translated on the basis of their semantic meaning, and the translation equivalents are descriptive and mostly nonidiomatic. The same observation can be made when studying Slovene PUs whose component is a common Slovene name or hypocorism. For instance:

kranjski Janez - 'Carniolan Janez' (= a Slovene boy/man $)^{4}$

kar se Janezek nauči, to Janez zna - 'Janez knows what Janezek learns' (= a grownup (Janez = John) knows how to do something that he learnt in his youth, i.e., when he was called Janezek = Johnny)

Janez in Micka - 'Janez and Micka' (= an average Slovene man (Janez = John) and an average Slovene woman (Micka which is a hypocorism of Marija, i.e., Mary)) hlapec Jernej - 'the bailiff Jernej' (= someone who fights unsuccessfully for the rights of the oppressed) $)^{5}$

${ }^{4}$ Carniola was a historical region that comprised parts of what is now Slovenia. As part of Austria-Hungary, the region was a crown land officially known as the Duchy of Carniola until 1918. Janez is a common Slovene name corresponding to John in English.

5 A hero in Ivan Cankar's Bailiff Yerney and His Rights. Cankar describes a clash between an 
Peter ali Pavel - 'Peter or Pavel' (= anyone $)^{6}$

mila Jera or mila jera - 'mild Jera' (= a defeatist person, crybaby) ${ }^{7}$

A name can change from a proper name to an appellative when a proper name takes on a metaphorical meaning. As Svensén (2009: 74) points out, the appellativization can be more or less 'forgotten', which may be manifested by the common noun's being written with a lower-case initial letter. The same phenomenon can also be observed in Slovene, e.g., bogat kot krez/Krez - (as) rich as Croesus. As is evident from this example, the use of a lower-case or upper-case initial may vary (as far as this PU is concerned, three hits can be found in the FidaPlus corpus; in two, krez is spelt with the lower case, whereas in one it is capitalized; for more about the inconsistencies in the Slovene spelling, cf. also Kržišnik, 2003). The Slovar slovenskega knjižnega jezika does not include this particular PU but lists the entry krez (spelt with the lower case) and defines it as 'a man of means'. In Slovene, personal names often become common nouns denoting people with very specific characteristics (e.g., jera in mila jera; pepe - a dull, awkward person; jure - a slightly dull, awkward person; micka - a woman, a girl). The reasons cannot be stated directly, but probably a person with a certain personal name possessing such characteristics used to live in the past (Snoj, 2003: 239).

The names of saints are often a component of Slovene PUs, especially proverbs and sayings referring to the time of the year, months, days or weather. Many of these are no longer used in daily conversation, but they still remain part of Slovene heritage and should therefore not be ignored. It should be stressed that in the past, the predominantly agricultural population depended on weather for their livelihood, and the proverbs and sayings often combine prediction of possible weather changes with relevant advice, warnings and general guidance. Weather change was often related to specific religious holidays or the feast days of different saints. As opposed to Slovene, there are only very few proverbs and sayings with saints' names in English (e.g., If St. Paul's Day be fair and clear, it will betide a happy year), which can be explained by the fact that the veneration of saints has been a wide-spread phenomenon in Slovenia, but not in England (Šabec, 2007: 268-270). It is very often of great importance to be familiar with the symbolism of the customs and festivities related to the feast day of a certain saint in order to

individual worker (Jernej = Bartholomew; the anglicized spelling of Jernej being Yerney) who fights for his rights in both the capitalist and traditional societies. Jernej symbolizes a farmhand without rights, the exploitation of farmhands, the unsuccessful quest for rights, doubts about the existence of rights and disappointment over laws and the Church.

${ }^{6}$ The names Peter and Paul (Pavel in Slovene) occur together in some phraseological units (also in English, cf. rob Peter to pay Paul), which is because these two apostles worked together (cf. Keber, 2007: 207-209).

${ }^{7}$ Probably from the female name Jera, which is a hypocorism of Gertrud. 
be able to understand the Slovene PU. Šabec (271) mentions the example of one proverb that is also included in our Slovene database: i.e., Če se Martinova gos po ledu plazi, o božiču navadno po blatu gazi ('If Martin's goose crawls over the ice, it usually flounders through the mud at Christmas'). If this proverb is to be fully understood, one has to know that St. Martin's (11 November) is a popular holiday in Slovenia, when must is turned into wine. It is a tradition to eat a dish of goose and drink some new wine. The examples below clearly show that the Slovene PUs with saints' names are highly culture-specific and thus understood only by native speakers of Slovene:

Če na Jakoba dežuje, ostro zimo oznanjuje. - 'If it rains on James's day, a harsh winter can be expected.' (the feast day of St. James is on 25 July)

Če na Marjeto dež lije, seno na travniku zgnije. - 'If it pours on Margaret's day, hay goes rotten in the meadow.' (the feast day of St. Margaret of Antioch is on 20 July) Sveti Vid je češenj sit. - 'Saint Vitus has had enough cherries to eat.' (Saint Vitus's Day is celebrated on 15 June when cherries are ripe)

O svetem Vidu se skozi noč vidi. - 'On the day of Saint Vitus you can see through the night.' (that means that the night is the shortest)

Sveti Matija led razbija, če ga ni, ga pa naredi. - 'Saint Matthias breaks the ice, but if there is no ice, he makes it.' (that means that around 24 February - the feast day of St. Matthias - the weather usually changes)

Unlike the previous five examples, where the name of a saint refers to his/her feast day, the following two examples do not belong to the group of proverbs and sayings but are pure idioms; thus, the saints' names are used in their connotative rather than denotative meaning:

blažev žegan - 'Blaise's blessing' (= something that is ineffective) $)^{8}$

babji gregor - 'women's Gregory' (= lady-killer)

Personal names are also used in folk tradition and are again limited to a specific culture:

kralj Matjaž - 'King Matjaž' (= a just ruler) ${ }^{9}$

${ }^{8}$ On 3 February, the feast day of St. Blaise, St. Blaise's blessing of throats is given. According to some explanations of this PU, people did not really believe in the blessing bestowed by the Church, although they used to attend such blessings in great numbers.

${ }^{9}$ King Matjaž is a legendary hero who is probably modelled on the figure of King Matthias Corvinus of Hungary. Legend has it that King Matjaž was a good king who was always ready to help. His time was a golden era for Carinthia. But other kings were envious of his power and united their armies against him. With only a hundred of his surviving soldiers, he had to hide in a cave that opened up under Mount Peca. The cave hid them from the enemies. In the cave, Matjaž sat at a 
spijo kot Matjaževa vojska - 'they sleep like Matjaž army' (= they sleep long and deeply)

English PUs containing a name and a family name are also culture-specific and more or less unknown to native speakers of other languages, including Slovene. Non-native speakers of English have probably never heard of Gordon Bennett (probably from Lieutenant-General Henry Gordon Bennett, who abandoned his command and fled to safety during the Japanese invasion of Singapore, leaving his unfortunate troops behind to be captured), Heath Robinson (an English artist who drew strange, complicated machines that could do simple jobs), John Hancock (the first person to sign the United States Declaration of Independence) or Rube Goldberg (an American who drew funny pictures for newspapers showing complicated inventions) although these people really existed. Also the PUs of this type referring to literary or cartoon characters, such as John Bull (from The History of John Bull written by John Arbuthnot in 1712), Johnny Canuck (a character in political cartoons), Simon Legree (the brutal slave dealer in Uncle Tom's Cabin), Peter Pan (the hero of Sir James M. Barrie's play about a boy who never grew up), may prove to be too culture-specific for non-native speakers of English and are therefore difficult, if not impossible, to decode without an additional explanation of their meaning. The same phenomenon can be observed when studying the Slovene PUs consisting of a name + family name, although not many exist in Slovene. For example:

Janez Novak - a typical ordinary Slovene male ${ }^{10}$

Martin Krpan - a strong $\operatorname{man}^{11}$

Peter Klepec - a strong man ${ }^{12}$

Undoubtedly, specific cultural connotations of the PUs consisting of a name + family name are restricted to the cultural area of either Great Britain or the USA in the case of English PUs or the cultural area of Slovenia in the case of Slovene PUs. Similar observations are made by Dobrovol'skij \& Piirainen (2005: 247).

As far as the English PUs with toponyms are concerned, the place names are mostly places in the UK, Ireland or Scotland (e.g., Bristol, Cheshire, Clapham,

table with the others around him and they fell asleep. When his beard has grown nine times around the stone table, he will wake up, come out of the cave, defeat all his enemies and bring a golden era to the Slovenes.

${ }^{10}$ Janez is a common Slovene name and Novak a common Slovene family name.

${ }^{11}$ A fictional character from Fran Levstik's Martin Krpan from Vrh, published in 1858. Martin Krpan symbolizes positive characteristics of the Slovene nation such as courage, strength, gratitude and humility.

${ }^{12}$ A legendary person of great strength from the Upper Kolpa Valley who, according to folk tradition, chased away the Turks. This folk hero used his strength to help others. 
Coventry, Forth Bridge, Kilkenny, Newcastle), places on the Continent (e.g., Rome, Waterloo) or places known from mythology (e.g., Charybdis, Rubicon, Scylla). Except for the PUs containing places from mythology (e.g., between Scylla and Charybdis - med Scilo in Karibdo, cross the Rubicon - prekoračiti Rubikon) and the very few PUs with a common cultural background (e.g., all roads lead to Rome - vse poti vodijo v Rim, somebody's road to Damascus - pot v Damask), whose equivalents in Slovene are lexically identical to the English PUs, other English PUs with place names have no counterparts in Slovene and are thus not understood by Slovene native speakers, the reason being that they are limited to a specific cultural background. For example:

(all) shipshape and Bristol fashion - pospravljen kot iz škatlice ('tidied up as from a box')

grin like a Cheshire cat - režati se kot pečen maček ('grin like a roasted cat')

wouldn't do something for all the tea in China - ne bi naredil kaj za nič na svetu ('wouldn't do something for anything in the world')

send somebody to Coventry - ne meniti se za koga, ne govoriti s kom ('not pay attention to somebody, not speak to somebody')

The PU carry/take coals to Newcastle, whose equivalent in Slovene is nositi vodo $v$ morje ('carry water to the sea'), has another equivalent in Slovene, i.e., nositi vodo $v$ Savo ('carry water to the Sava River'), which contains a proper name. The latter, however, is obsolete. Interestingly, Piirainen (2002: 350) establishes that the German PU Wasser in den Fluss tragen ('carry water to the river') has about 20 adaptations to particular regions by means of varying river names (e.g., Wasser in den Rhein/die Donau/Saar/Spree, etc. tragen ('carry water to the Rhine/Danube/ Saar/Spree, etc.')). Another interesting example in English is the PU meet one's Waterloo - doživeti poraz ('experience defeat'). In Slovene, 'doživeti svoj Waterloo' (which is a literal translation of the English PU) can be found in the FidaPlus corpus (10 hits), although it is questionable whether native speakers of Slovene would understand it, since they may not know what is implied in the meaning of the word 'Waterloo'; in other words, they would have to be familiar with the historical background if they wanted to understand the figurative meaning.

Slovene PUs containing a place name or a derivative from a place name are also highly culture-specific. PUs may contain a typical Slovene place name, which has a certain connotation known to Slovene native speakers, but which is not understood outside Slovenia. For example:

odpeljati koga v Polje - 'take somebody to Polje' (= take somebody to the Ljubljana psychiatric hospital, which is situated in the part of Ljubljana called Polje). In other regions of Slovenia, psychiatric patients are taken to other psychiatric hos- 
pitals located in different places, such as Begunje, Vojnik and Idrija; therefore, the PUs 'take somebody to Begunje/Vojnik/Idrija' are used. It should be stressed that Szerszunowich (2008: 119) finds the model 'go to [name of a place where the nearest mental hospital is situated]' being used to express the meaning that 'somebody is crazy' in a great number of languages, for example Croatian, Italian and Polish, which is in line with our observations. Dobrovol'skij and Piirainen (2005: 246) mention another example taken from German phraseology, i.e., the names of the rivers that are interchangeable according to the particular river of a given region of the German-speaking countries. For example: mit Spreewasser getauft sein - be baptized with water from the Spree ('be a native of Berlin') or mit Alsterwasser getauft sein - be baptized with water from the Alster ('be a native of Hamburg'); Spree and Alster being the rivers flowing through Berlin and Hamburg, respectively.

Zgornji Kašelj - 'Upper Kašelj' (= an unimportant small place). The village called Kašelj really exists but a question can be raised why Kašelj in combination with Zgornji has become a PU with the above-mentioned meaning. According to Žagar Karer (2008: 118), this may be due to its unusual name (kašelj means 'cough') and to the fact that the smallness of this village is additionally emphasized by the division of the place into two parts: i.e., Spodnji Kašelj ('Lower Kašelj') and Zgornji Kašelj. In fact, Spodnji Kašelj may be used in the same sense as Zgornji Kašelj.

kralj na Betajnovi - 'king of Betajnova' (= a person in a superior position). Jožef Kantor, called the king of Betajnova (= Betajnova is a part of the town of Vrhnika), is a hero of Ivan Cankar's drama with the same title. He symbolizes power and the destruction of the weak, while assuaging a bad conscience.

A Slovene PU may consist of a foreign place name or a derivative from a foreign place name although this does not facilitate comprehension among nonnative speakers of Slovene, since such PUs are also culture-specific. For example:

odkriti Ameriko - 'discover America' (= discover something new)

stric iz Amerike - 'uncle from America' (= a rich and generous person)

videti Benetke - 'see Venice' (= be badly beaten, not get what one expects)

biti bizantinec - 'be a Byzantine' (= be a bootlicker, be a servile and smooth person)

palin mirna Bosna - 'and peaceful Bosnia' (used to express that we won't talk about it any longer)

kdor hoče iti na Dunaj, mora pustiti trebuh zunaj - 'one who wants to go to Vienna has to leave his/her stomach outside' (= life in Vienna is very expensive)

delati se Francoza or narediti se Francoza - 'pretend to be a Frenchman' (= pretend 
not to understand/know/notice something)

oditi/popihati jo po francosko - 'leave/run away in a French way' (= leave/run away without saying goodbye or without being noticed)

iti v Rim - 'go to Rome' (= give birth)

biti spanska vas - 'be a Spanish village' (= be totally unknown to somebody) $)^{13}$ kaditi kot Turek - 'smoke like a Turk' (= smoke heavily)

biti izmučen/zbit kot turška fana - 'be tired like a Turkish flag' (= be very tired) pravi Teksas - 'real Texas' (= a dangerous place with much criminal activity $)^{14}$

The Slovene database includes a number of PUs containing the noun cigan (= Gypsy):

lagati kot cigan - 'lie like a Gypsy' (= lie frequently)

biti cigan - 'be a Gypsy' (= be badly dressed)

(kje) je kot pri ciganih - 'it's like at the Gypsies" (= everything is in a terrible mess) biti pravi cigan - 'be a real/true Gypsy' (= be a cunning, careless or good-fornothing person)

It is obvious that they all have negative connotations, which can be explained by the fact that the members of this ethnic group have always been stigmatized in Slovene society.

All in all, the analysis of the English and Slovene PUs with an onomastic component clearly indicates that the majority of PUs in both languages are highly culture-specific. If a PU with an anthroponym is an allusion to antiquity, the Greek or Roman cultural heritage, ancient history and if it has certain literary connotations, it is less problematic or not problematic at all in the process of decoding. The same holds true of PUs with toponyms whose connotations are universal, since they may originate from the common background, are connected with events of particular significance, and are universally known to the vast majority of language users.

${ }^{13}$ In English, corresponding idiomatic equivalents would be: be a closed book, something is double Dutch (to somebody) and it's (all) Greek to me. The last two PUs also have a derivative from a place name as a component. According to Keber (2007: 113), the PU španska vas comes from the German PU für jemanden spanische Dörfer sein, which is mixture of two PUs, i.e., das ist mir spanisch (used in reference to the Spanish and German king Charles V, who introduced unknown customs to the German lands) and für jemanden böhmische Dörfer sein (Germans did not understand the names of the Czech (= böhmisch) villages).

${ }^{14}$ The US state of Texas is stereotyped as a state with many murder cases and criminal acts. 


\section{CONCLUSION}

Without a shadow of a doubt, PUs with an onomastic element are often culturally specific because they refer to a unique denotatum belonging to the national culture. They absorb and accumulate cultural elements that are handed down and integrated into the cultural memory by permanent use of these phraseological expressions.

As is evident from the analysis of both English and Slovene PUs, the salient feature is that reference in English as well as in Slovene PUs is often made to people or places with which the members of the respective culture (either British or Slovene) are familiar. Proper names that are characteristic of a given culture should be observed from different points of view, ranging from historical and geographical to cultural, linguistic, cross-linguistic and social. Many PUs are motivated by extralinguistic phenomena belonging to the collective memory of a given nation (cf. Szerszunowicz, 2008: 118-119). Here, we can agree with Pierini (2008: 7) that in this case, denotational and connotational meaning is established by extracting important pieces of information from world knowledge associated with each of them. If this is not the case, the process of decoding such a PU may pose problems or may even result in an incorrect interpretation or translation.

It is essential to be aware of the importance of the relationship between language and culture because of the high cultural specificity of PUs whose comprehension and translation depend considerably on knowledge of the universal, national or local character of such units. This is also reflected in the (English as well as Slovene) PUs studied in our research where only very few parallels with the same proper name can be found between the two languages. A more thorough study of culture-specific PUs with onomastic elements from different perspectives would doubtlessly contribute to a higher level of cross-cultural awareness.

\section{REFERENCES}

Cowie, Anthony Paul. (1992). Multiword lexical units and communicative language teaching. In P. J. L. Arnaud \& Henri Béjoint (eds.), Vocabulary and applied linguistics (pp. 1-12). London: Macmillan.

Dobrovol'skij, Dmitrij \& Piirainen, Elisabeth. (2005). Figurative language: Crosscultural and Cross-linguistic perspectives. Amsterdam, Boston, Heidelberg, London, New York, Oxford, Paris, San Diego, San Francisco, Singapore, Sydney, Tokyo: Elsevier.

FidaPlus corpus: http://the.sketchengine.co.uk/bonito/run.cgi/first_form?corpna me= preloaded/fidaplus 2 .

Gläser, Rosemarie. (1984). Terminological problems in linguistics, with special 
reference to neologisms. In Reinhard Rudolf Karl Hartmann (ed.), LEXeter '83 Proceedings (pp. 345-351) (Lexicographica Series Maior 1). Tübingen: Max Niemeyer Verlag.

Gläser, Rosemarie. (1988). The grading of idiomaticity as a presupposition for a taxonomy of idioms. In Werner Hüllen \& Rainer Schulze (eds.), Understanding the lexicon (264-79). Tübingen: Max Niemeyer Verlag.

Gläser, Rosemarie. (1998). The stylistic potential of phraseological units in the light of genre analysis. In Anthony Paul Cowie (ed.), Phraseology: Theory, analysis, and applications (pp. 125-143). Oxford: Oxford University Press.

Granger, Sylviane \& Meunier, Fanny. (2008). Phraseology: An interdisciplinary perspective. Amsterdam, Philadelphia: John Benjamins Publishing Company.

Keber, Janez. (2007). Pavle je Pavel, a ni bil Savel, tudi ni Peter in Pavel ne Peter ali Pavel ne pavliha. Jezikoslovni zapiski, 13 (1-2), 203-215.

Kržišnik, Erika. (2003). Frazeologija v Slovenskem pravopisu 2001. Slavistična revija, 51 (2), 221-239.

Kržišnik, Erika. (2008). Viri za kulturološko interpretacijo frazeoloških enot. Jezik in slovstvo, 53 (1), 33-47.

Kržišnik, Erika (2010). Idiomatska beseda ali frazeološka enota. Slavistična revija, 58 (1), 83-94.

Kunin, Aleksandr Vladimirovich. (1970). Angliyskaya frazeologiya: teoreticheskiy kurs. Moskva: Vysshaya shkola.

Lyons, John. (1977). Semantics. Cambridge: Cambridge University Press.

Mel'čuk, Igor A. (1995). Phrasemes in language and phraseology in linguistics. In Martin Everaert, Erik-Jan van der Linden, André Schenk \& Rob Schreuder (eds.), Idioms: Structural and psychological perspectives (pp.167-232). Hillsdale, NJ: Lawrence Erlbaum Associates.

Moon, Rosamund. (1992a). There is reason in the roasting of eggs. In Hannu Tommola, Krista Varantola, Tarja Salmi-Tolonen \& Jürgen Schopp (eds.), Euralex '92 Proceedings (pp. 493-502). II (Studia Translatologica ser. A, 2). Tampere: University of Tampere.

Moon, Rosamund. (1992b). Textual aspects of fixed expressions in learners' dictionaries. In P. J. L. Arnaud \& Henri Béjoint (eds.), Vocabulary and applied linguistics (13-27). London: Macmillan.

Moon, Rosamund. (1998a). Fixed expressions and idioms in English: A Corpusbased Approach. Oxford: Clarendon Press.

Moon, Rosamund. (1998b). Frequencies and forms of phrasal lexemes in English. In: Anthony Paul Cowie (ed.), Phraseology: Theory, analysis, and applications (79-100). Oxford: Oxford University Press..

Naciscione, Anita. (2010). Stylistic use of phraseological units in discourse. Amsterdam, Philadelphia: John Benjamins Publishing Company.

Quirk, Randolph, Greenbaum, Sidney, Leech, Geoffrey \& Svartvik, Jan. (1985). 
A comprehensive grammar of the English language. London, New York: Longman.

Pierini, Patrizia. (2008). Opening a Pandora’s box: Proper names in English phraseology. Linguistik online, 36 (4), 43-58. [Online] Available at http:// www.linguistik-online.de/36_08/pierini.html. Accessed on: 10 January 2013.

Piirainen, Elisabeth. (2002). Bier mit ins Hofbräuhaus nehmen oder Sand in die Sahara tragen? Nochmals zum Idiomtyp 'Eulen nach Athen tragen'. Proverbium. Yearbook of International Proverb Scholarship, 19, 349-359.

Šabec, Nada. (2007). Weather proverbs in Slovene and English. In Erika Kržišnik \& Wolfgang Eismann (eds.), Frazeologoija v jezikoslovju in drugih vedah: Europhras Slovenija 2005 (pp. 267-275). Ljubljana: Filozofska fakulteta.

Svensén, Bo. (2009). A handbook of lexicography: The theory and practice of dictionary-making. Cambridge: Cambridge University Press.

Svensson, María Helena. (2008). A very complex criterion of fixedness: Noncompositionality. In Sylviane Granger \& Fanny Meunier (eds.), Phraseology: An interdisciplinary perspective (pp. 81-93). Amsterdam, Philadelphia: John Benjamins Publishing Company.

Szerszunowicz, Joanna. (2008). Decoding phraseological units as a socio-linguistic problem (on the example of onomastic Idioms). Nation and language modern aspects of socio-linguistic development, Third conference (pp. 118-121). Kaunas: Kauno technologijos universiteto, Panevéžys Institute Centre of Languages. [Online] Available at http://www.google.si. Accessed on: 10 January 2013.

Szerszunowicz, Joanna. (2009). Some remarks on the evaluative connotations of toponymic idioms in a contrastive perspective. In Roberta Corrigan, Edith A. Moravcsik, Hamid Ouali \& Kathleen M. Wheatley (eds.), Formulaic language, distribution and historical change, Vol. 1 (pp. 171-181). Amsterdam, Philadelphia: John Benjamins Publishing Company.

Teliya, Veronika, Bragina, Natalya, Oparina, Elena \& Sandomirskaya, Irina. (1998). Phraseology as a language of culture: Its role in the representation of a collective mentality. In Anthony Paul Cowie (ed.), Phraseology: Theory, Analysis, and Applications (pp. 55-75). Oxford: Oxford University Press.

Verstraten, Linda. (1992). Fixed phrases in monolingual learners' dictionaries. In P. J. L. Arnaud \& Henri Béjoint (eds.), Vocabulary and Applied Linguistics (2840). London: Macmillan.

Weisgerber, J. L. (1929). Muttersprache und Geistesbildung. Göttingen: Vandenhoeck \& Ruprecht.

Žagar Karer, Mojca. (2008). Geografski termini in frazeologija. Jezikoslovni zapiski, 14 (2), 101-122. 


\section{DICTIONARIES}

Bajec, Anton; Inštitut za slovenski jezik (Slovenska akademija znanosti in umetnosti) (eds.) (2000). Slovar slovenskega knjižnega jezika z odzadnjim slovarjem slovenskega jezika in besedišcem slovenskega jezika z oblikoslovnimi podatki. Ljubljana: DZS [CD-ROM version].

Brown, Keith et al. (eds.) (2001). Oxford Idioms Dictionary for Learners of English. Oxford: Oxford University Press.

Flavell, Linda \& Flavell, Roger. (1994). Dictionary of Idioms and their Origins. London: Kyle Cathie Limited.

Hands, Penny. (1996). Chambers English Dictionary of Idioms. Edinburgh: Chambers Harrap Publishers.

Keber, Janez. (2003). Frazeološki slovar slovenskega jezika: poskusni zvezek. Ljubljana: Založba ZRC SAZU.

McCarthy, Michael (ed.) (1998). Cambridge International Dictionary of Idioms. Cambridge: Cambridge University Press.

Sinclair, John (ed.) (1995). Collins COBUILD Dictionary of Idioms. London: HarperCollins Publishers.

Snoj, Marko. (2003). Slovenski etimološki slovar. (2 ${ }^{\text {nd }}$ ed.). Ljubljana: Modrijan. 